\title{
Comparative Studies of Oleaginous Fungal Strains (Mucor circinelloides and Trichoderma reesei) for Effective Wastewater Treatment and Bio-Oil Production
}

\author{
Anshuman Bhanja, ${ }^{1}$ Gauri Minde, ${ }^{2}$ Sandip Magdum, ${ }^{2}$ and V. Kalyanraman ${ }^{2}$ \\ ${ }^{1}$ Department Biotechnology, Indian Institute of Technology Guwahati, Guwahati 781039, India \\ ${ }^{2}$ COE Biotechnology, R.D. Aga Research, Technology and Innovation Centre, Thermax Ltd., Pune 411019, India
}

Correspondence should be addressed to Sandip Magdum; sandip.magdum@thermaxindia.com

Received 13 August 2014; Revised 27 September 2014; Accepted 2 October 2014; Published 2 November 2014

Academic Editor: Shengwu Ma

\begin{abstract}
Copyright (c) 2014 Anshuman Bhanja et al. This is an open access article distributed under the Creative Commons Attribution License, which permits unrestricted use, distribution, and reproduction in any medium, provided the original work is properly cited.
\end{abstract}

\begin{abstract}
Biological wastewater treatment typically requires the use of bacteria for degradation of carbonaceous and nitrogenous compounds present in wastewater. The high lipid containing biomass can be used to extract oil and the contents can be termed as bio-oil (or biodiesel or myco-diesel after transesterification). The separate experiments were conducted on actual wastewater samples with $5 \% \mathrm{v} / \mathrm{v}$ inoculum of Mucor circinelloides MTCC1297 and Trichoderma reesei NCIM992 strains. The observed reductions in chemical oxygen demand (COD) were $88.72 \%$ and $86.75 \%$ in 96 hrs and the observed substrate based biomass yields were $0.21 \mathrm{mg}$ VSS/mg COD and $0.22 \mathrm{mg}$ VSS/mg COD for $M$. circinelloides reactor and for T. reesei reactor, respectively. The resulted bio-oil production from wastewater treatment by $M$. circinelloides and T. reesei reactors was $142.2 \mathrm{mg} / \mathrm{L}$ and $74.1 \mathrm{mg} / \mathrm{L}$, whereas biomass containing biooil contents $(\% \mathrm{w} / \mathrm{w})$ were $22.11 \%$ and $9.82 \%$, respectively. In this experiment, the fungal wastewater treatment was also compared with conventional bacterial process with respect to specific growth rate, biomass production, and oil content. This study suggests that wastewater can be used as a potential feedstock for bio-oil production with the use of oleaginous fungal strains and which could be a possible route of waste to energy.
\end{abstract}

\section{Introduction}

The efficient use of organic cycle via waste to energy configuration can contribute to reducing the current energy crisis. Numbers of countries in the world, including India, are currently passing through the critical phase of population explosion and the growing population demands more energy inputs [1]. Therefore, to ensure long-term sustainability, suitable alternative methods for oil production have to be developed which can be used as feedstock for several industrial applications [2]. Various wastes to energy conversion possibilities were explored till date, like kitchen waste to biogas [3], plant/agriculture waste to alcohol [4], anaerobic wastewater treatment to biogas [5], and wastewater treatment by using microbial fuel cell to produce hydrogen and electricity [6].
Basically, bacterial system is ideal for wastewater treatment due to its high rate of organic degradation. In case of yeast, they have fast growth rate compared to fungi and also found the oil assimilating capacity; in the recent study, researchers successfully used high strength brewery effluents for the production of microbial lipids for biodiesel production by using yeast Rhodotorula glutinis [7]. A similar study was effectively carried out by using high organic strength starch wastewater treated with the same yeast, Rhodotorula glutinis. Some other types of yeast also reported for high strength wastewater treatment with bio-oil production, such as Trichosporon dermatis and Rhodosporidium toruloides Y2, were used to treat wastewater from ethanol fermentation $[8$, 9]. But use of sewage wastewater or low strength wastewater for bio-oil or biodiesel production by using yeast or fungi has not been very well reported. Fungi are also known for their 
efficient carbon reduction and responsible for degradation of various tough to degrade substrates, such as polyvinyl alcohol [10]. There have been a few explorations into this technology, but most of them aim at growing fungi in nutrient media or synthetic substrates and then extracting lipids through them $[11,12]$. Due to some characteristics like slow growth rate compared to bacteria (faster than algae), acidic $\mathrm{pH}$ requirement, filamentous growth, and spore forming nature, not many researchers have conducted experiments by using fungi to produce lipids from wastewater and hardly any commercial options are available. Some studies of high organic concentrations effluent were carried out for fungal bio-oil production.

Hence, not much research has gone into fungal wastewater treatment despite the lipid production being an advantage. Certain strains, such as Aspergillus oryzae, Rhodosporidium toruloides, Epicoccum purpurascens, Lipomyces starkeyi, Trichosporon dermatis, Mortierella isabellina, and Mucor circinelloides, are known to accumulate high amounts of lipids and the lipid content ranging between 18.1 and $42.6 \%$ of their biomass and are thus called oleaginous strains [13-20]. The fatty acid profiles of microbial bio-oils are quite similar to those of conventional vegetable oils; hence, oleaginous filamentous fungi are suggested as a favorable feedstock for a sustainable biodiesel industry $[15,21]$. In this context, the wastewater can be considered as a cost-effective candidate of raw materials for biodiesel production [22]. Biodiesel has the ability to mix with petroleum diesel in any ratio and still function; biodiesel can be considered as a clean and renewable first alternative solution to oily energy resource [23].

This work aims at producing value added product in the form of bio-oil which would be an energy source produced in parallel with fungi based wastewater treatment. The fungal wastewater treatment can overcome the sludge handling as one of the disadvantages of the traditional bacterial wastewater treatment.

\section{Materials and Methods}

2.1. Wastewater Sample and Inoculum Preparation. 10 liters of wastewater sample was collected from the equalization tank of ETP present in factory premises of Thermax Ltd. located at Pune, India. The collected wastewater sample was analyzed for COD, TOC, pH, NH3-N, and phosphate. Mucor circinelloides (MTCC1297; Microbial Type Culture Collection, India) and Trichoderma reesei (NCIM992; National Collection of Industrial Microorganisms, India) were selected and collected as inoculum as they are reported to be high lipid yielding fungi. Two sets of $500 \mathrm{~mL}$ Sabouraud Agar broth (HiMedia Ltd.) (30 gm of dry Sabouraud Agar broth in $1 \mathrm{~L}$ distilled water, $\mathrm{pH}$ 5.8) in 1 lit conical flasks separately were autoclaved and cooled in water bath to room temperature. Further, the flasks containing broths were inoculated separately with lyophilized cultures of $M$. circinelloides and $T$. reesei. The two flasks were left on a rotary shaker at 120 RPM speed for 6 days at room temperature for both fungal cultures to grow as inoculum. The bacterial sludge was collected from tube settler out of nearby MBBR plant as inoculum for third reactor for comparison with conventional bacterial wastewater process.

2.2. Experimentation. The $\mathrm{pH}$ was reduced to 4.97 of actual wastewater (6 liter) with COD of $2862.16 \mathrm{mg} / \mathrm{L}$ being taken. This was divided into three equal portions and poured into three bottles with 3 liter volume. Aeration pipes with bubbler stones were inserted and the bottles were cotton plugged with cotton and the three systems were autoclaved for 15 minutes at $110^{\circ} \mathrm{C}$ with 15 psi pressure to avoid bacterial contamination and then cooled to room temperature. Since the fungal inoculums were incubated on a rotary shaker, the fungal flocks formed, which were roughly spherical masses of different sizes ranging from 0.6 to $0.9 \mathrm{~cm}$. The $100 \mathrm{~mL}$ of inoculums of the two fungal strains $(M$. circinelloides and T. reesei) and bacterial sludge was centrifuged and washed repeatedly with autoclaved distilled water and the same was inoculated into their respective 3 liter bottles containing wastewater as a substrate aseptically. The reactors were started with aeration rate $8 \mathrm{LPM}$ and reactor samples were obtained on 1st, 2 nd, 3 rd, and 4 th days. The samples were filtered and the TOC was determined and the $\mathrm{pH}$ was recorded with a Jenco $6230 \mathrm{MpH}$ meter (Jenco Instruments, San Diego, CA) for each sample. The samples from fungal reactors were analyzed under a microscope with 40x magnification (Dewinter Trinocular Microscope-Model: Select) to check for bacteria contaminations.

2.3. Bio-Oil Extraction. The fungal and bacterial biomasses from each bioreactor were collected and dried at $60^{\circ} \mathrm{C}$. The samples of dry masses were then crushed with mortar and pestle and added to $10 \mathrm{~mL}$ of distilled water. $2 \mathrm{~mL} 1: 1$ sulphuric acid was added and then $25 \mathrm{~mL}$-hexane was added to the mixture to dissolve the lipids. The solutions were left on a rotary shaker overnight. The layer of hexane was extracted out and filtered through a 40 Whatman filter paper with $6 \mathrm{gm}$ of sodium sulphate. The filtrate was then poured into a dry crucible (whose dry weight was measured) and heated at $60^{\circ} \mathrm{C}$ for the hexane to vaporize leaving only the lipid. The total weight was measured. The oil extraction procedure was repeated for all the fungal and bacterial biomasses. The weight differences for the respective fungal and bacterial samples were recorded.

2.4. Analytical Methods. The COD (APHA method 5220B), NH3-N (APHA method number: 4500-NH3 E), and phosphate (APHA method: 4500-P C) of water samples were used according to the procedure described in Standard Methods [24]. Total suspended solids and fixed and volatile solids were analyzed by procedure described in Standard Methods (APHA method: 2540 D \& E). The total organic carbon (TOC) analysis of all samples was carried by TOC-V CPH (Shimadzu Ltd.) with multiplying factor of 2.66 for final indirect COD quantification [25]. 


\section{Results and Discussions}

3.1. Fungal Organic and Nutrient Reduction. Initial COD, NH3-N, and phosphate concentrations of wastewater sample with inoculum were $2862.16 \mathrm{mg} / \mathrm{L}, 41.5 \mathrm{mg} / \mathrm{L}$, and $17.38 \mathrm{mg} / \mathrm{L}$, respectively. The percentage COD reductions were $68.38 \%$ and $21.5 \%$ for $M$. circinelloides inoculated and T. reesei inoculated reactors on first day, respectively (Figure 1(a)). Whereas The COD reduction rates on first and second day of TR were $2.27 \mathrm{mg}$ COD/mg VSS.d and $3.22 \mathrm{mg} \mathrm{COD} / \mathrm{mg}$ VSS.d, respectively, indicating slightly increased respiratory activity on second day (Figure 1(b)). It indicates that $M$. circinelloides reduces COD, probably rbCOD at higher rate than $T$. reesei, which reduces $\mathrm{COD}$ at slower but consistent rates. By the end of the fourth day of batch process, the COD, NH3-N, and phosphates of $M$. circinelloides and T. reesei reactor samples were $322.92 \mathrm{mg} / \mathrm{L}, 4.66 \mathrm{mg} / \mathrm{L}$, and $2.08 \mathrm{mg} / \mathrm{L}$ and $379.32 \mathrm{mg} / \mathrm{L}, 5.89 \mathrm{mg} / \mathrm{L}$, and $3.67 \mathrm{mg} / \mathrm{L}$, respectively.

3.2. Fungal Biomass Production. After inoculation of $M$. circinelloides and T. reesei to their respective reactors containing wastewater, their initial VSS was $109.86 \mathrm{mg} / \mathrm{L}$ and $208.57 \mathrm{mg} / \mathrm{L}$, respectively (Figure 2(a)). The biomass yield of $T$. reesei was $0.22 \mathrm{mg} \mathrm{VSS} / \mathrm{mg} \mathrm{COD}$, which was more than $M$. circinelloides yield ( $0.21 \mathrm{mg} \mathrm{VSS} / \mathrm{mg} \mathrm{COD})$, probably due to higher initial biomass concentration. The final VSS concentrations of $M$. circinelloides and $T$. reesei reactors were $643.1 \mathrm{mg} / \mathrm{L}$ and $754.8 \mathrm{mg} / \mathrm{L}$, which were less than VSS yield of $1.36 \mathrm{gm} / \mathrm{L}$ at high glucose concentration reported by Xia et al. [20]. Another study of $M$. isabellina with glucose being a substrate resulted in $17.5 \mathrm{~g} / \mathrm{L}$ of biomass, containing $12.7 \mathrm{~g} / \mathrm{L}$ of lipid, with lipids representing about $90-92 \% \mathrm{w} / \mathrm{w}$ [31]. This represents the use of simple sugars favored by fungi for its growth. The specific growth rates of $M$. circinelloides and T. reesei reactors were compared and found to be $1.083 \mathrm{mg} \mathrm{VSS} / \mathrm{mg} \mathrm{VSS} \cdot \mathrm{d}$ and $0.461 \mathrm{mg} \mathrm{VSS} / \mathrm{mg}$ VSS.d, respectively, after $24 \mathrm{hrs}$ (Figure 2(b)). The specific growth rate for $M$. circinelloides reactor gradually decreased and it was $0.075 \mathrm{mg}$ VSS/mg VSS. $d$ at the end of the fourth day, whereas, in case of the T. reesei reactor, the specific growth rate was increased to $0.498 \mathrm{mg} \mathrm{VSS} / \mathrm{mg} \mathrm{VSS} \cdot \mathrm{d}$ on the 2nd day and further it decreased to $0.104 \mathrm{mg}$ VSS/mg VSS.d at the fourth day. In the present experiment, although the M. circinelloides showed slightly lower biomass production rate, it had high specific growth rate compared to TR. The microscopy and biomass images of $M$. circinelloides and $T$. reesei were observed at day 4 (Figure 3 ).

3.3. Fungal Bio-Oil Production. At the end of wastewater treatment, the biomasses of $M$. circinelloides and T. reesei were used for bio-oil extraction. The net dry biomass weights collected from the $M$. circinelloides and T. reesei reactors were $1286.2 \mathrm{mg}$ and $1509.6 \mathrm{mg}$, respectively, per two liter cultures. $284.43 \mathrm{mg}$ and $148.2 \mathrm{mg}$ were the oil recovered from extraction process from $M$. circinelloides and $T$. reesei dry biomasses. The present wastewater treatment produced biooil yields were $142.2 \mathrm{mg} / \mathrm{L}$ and $74.1 \mathrm{mg} / \mathrm{L}$ for $M$. circinelloides and T. reesei reactors, respectively. The bio-oil content (\% $\mathrm{w} / \mathrm{w}$ ) was calculated, which was $22.11 \%$ and $9.82 \%$ for both M. circinelloides and T. reesei strains, respectively. M. circinelloides is reported with the lipid accumulation capacity of $25 \%$ of the cell biomass [32], whereas the fungal cultivation on thin stillage for 2 days in a $6 \mathrm{~L}$ airlift bioreactor, resulted in $92 \%$ increase in oil yield and $20 \mathrm{gm} / \mathrm{L}$ of dry fungal biomass with a lipid content of $46 \%$ (gm of oil per $100 \mathrm{~g}$ dry biomass) [33]. The study of liquid media containing high strength oil mill wastewater as sole carbon source showed that the T. elegans and Z. moelleri produced 4.4 and $3.5 \mathrm{gm} / \mathrm{L}$ cell mass in surface (SC) and submerged (SMC) cultures, respectively, containing around $60 \%(\mathrm{w} / \mathrm{w})$ of lipids [34]. In the present study of low strength fungal wastewater treatment, the $M$. circinelloides was observed to be the highest oil yielding fungal strain in comparison with $T$. reesei. Different types of substrate used for bio-oil accumulation in respective fungus were compared in Table 1 for their oil generation ability.

3.4. Comparative Evaluation of the Fungal Processes with Conventional Bacterial Wastewater Degradation Study. Conventional bacterial process will always be a high rate degradation process. The comparative figures are shown in Table 2. The conventional bacterial wastewater treatment showed high maximum specific growth rate compared to both $M$. circinelloides and T. reesei. The conventional bacterial process has taken 48 hours to cross the $90 \%$ COD reduction from $2862.16 \mathrm{mg} / \mathrm{L}$ to $280.90 \mathrm{mg} / \mathrm{L}$ where as both fungal had not reached at the end of fourth day. So the conventional bacteria process shows maximum COD reduction in minimum time. Similarly, the total biomass production was higher in the conventional bacterial process than with the fungal process. But fungi could offer the benefit over bacteria in wastewater treatment processes, as the biomass produced during fungal wastewater treatment has, potentially, a much higher value than that from the conventional bacterial activated sludge process [35]. The bio-oil content in conventional bacterial process was nearly seven times lesser than $M$. circinelloides and three times less than $T$. reesei.

3.5. Cost Benefits Analysis. A different form of biomass with a higher value could significantly change the economics of wastewater treatment [35]. Only saponifiable lipids and free fatty acids could be produced to fatty acid methyl esters (FAMEs) which are suitable for biodiesel production. It is reported that $98 \%$ of the total lipids extracted from $M$. circinelloides were saponifiable lipids and free fatty acids and the oil composition met the specifications of the current existing standards of hydrocarbons [36]. While estimating the potential of wastewater to bio-oil synthesis for biodiesel production via fungal ( $M$. circinelloides) route, the $100 \mathrm{~m}^{3} /$ day capacity plant having wastewater with similar characteristics can produce $14.22 \mathrm{~kg}$ of bio-oil per day and $200 \mathrm{MLD}$ plant can produce 28.44 tons of bio-oil per day (Table 3). Considering the above mentioned $98 \%$ saponifiable lipids content with $0.87 \mathrm{ton} / \mathrm{m}^{3}$ density of biodiesel, the theoretical biodiesel production will be $4.23 \mathrm{gal} / \mathrm{day}$ and $8436.87 \mathrm{gal} / \mathrm{day}$ with potential worth of 12.57 /day and 25137.7 /day for 
TABLE 1: Different substrates used and bio-oil content in respective fungus were compared.

\begin{tabular}{|c|c|c|c|}
\hline Substrate type & Fungi cultivated & Lipid accumulation (wt/wt) & Ref. \\
\hline \multirow{2}{*}{ Glucose, with N limitation and xylose induction } & Cunninghamella echinulata ATHUM 4411 & $57.70 \%$ & \multirow{2}{*}[26]{} \\
\hline & Mortierella isabellina ATHUM 2935 & $65.50 \%$ & \\
\hline Lactose & Mortierella isabellina & $36 \%$ & {$[27]$} \\
\hline Glucose, fructose, and sucrose & Thamnidium elegans CCF-1465 & $70 \%$ & {$[28]$} \\
\hline Sweet sorghum extract & Mortierella isabellina & $51 \%$ & [29] \\
\hline Rice hull hydrolysate & Mortierella isabellina & $64.30 \%$ & {$[30]$} \\
\hline \multirow{2}{*}{ Low strength wastewater } & Mucor circinelloides MTCC1297 & $22.11 \%$ & \multirow{2}{*}{ Present study } \\
\hline & Trichoderma reesei NCIM992 & $9.82 \%$ & \\
\hline
\end{tabular}

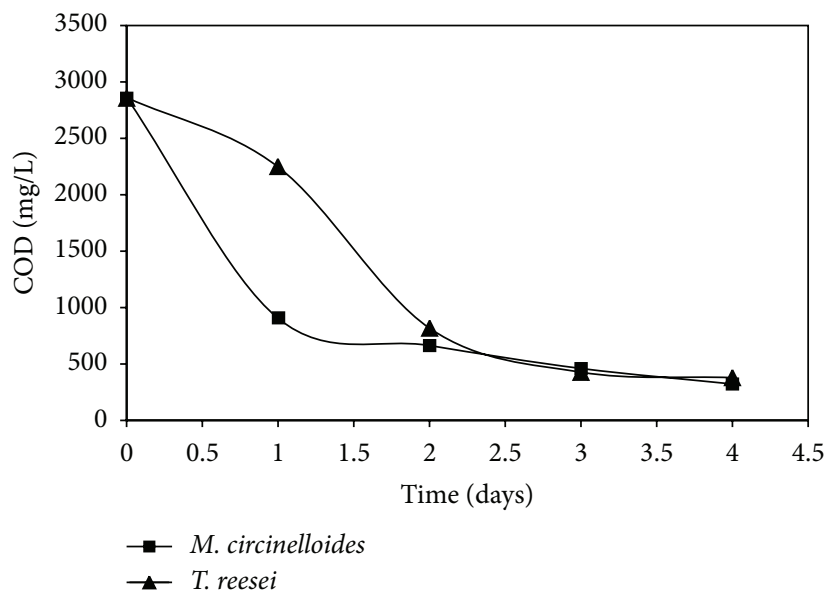

(a)

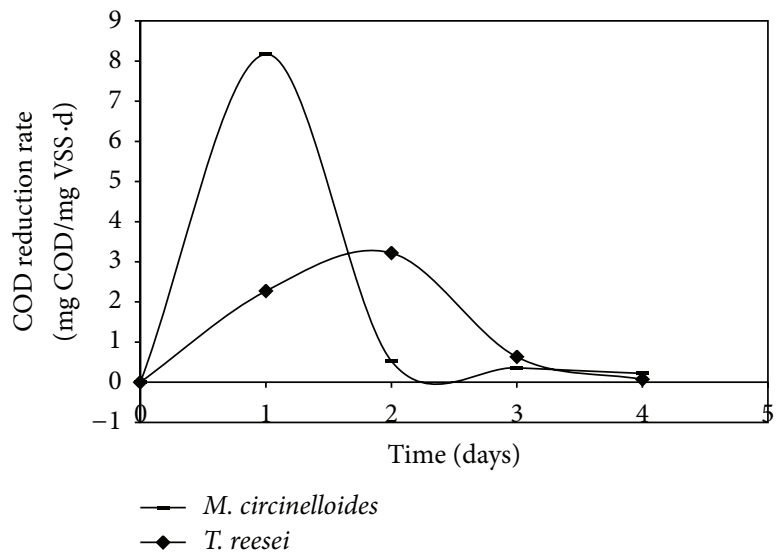

(b)

FIGURE 1: COD reduction and rate profile during fungal wastewater treatement. (a) Effect of different fungal strain inoculums (M. circinelloides and T. reesei) on COD reduction profile and (b) effect of different fungal strain inoculum on COD reduction rates.

TABLE 2: Comparison of maximum specific growth rate, \% COD reduction, biomass produced, and bio-oil content for different process inoculums.

\begin{tabular}{lcccc}
\hline $\begin{array}{l}\text { Wastewater process inoculum } \\
\text { type }\end{array}$ & $\begin{array}{c}\text { Maximum specific growth rate } \\
\text { mg VSS/mg VSS·d }\end{array}$ & $\begin{array}{c}\text { Time required for } \\
90 \% \text { COD reduction }\end{array}$ & $\begin{array}{c}\text { Total biomass produced } \\
\text { hrs }\end{array}$ & gm/lit \\
\hline Mucor circinelloides & 1.083 & $>96$ & 0.60 & 22.11 \\
Trichoderma reesei & 0.498 & $>96$ & 0.68 & 9.82 \\
Conventional bacterial process* & 1.343 & 48 & 1.55 \\
\hline
\end{tabular}

${ }^{*}$ The bacterial inoculum used in this process was collected from tube settler of MBBR plant, containing mixed bacterial flora. 


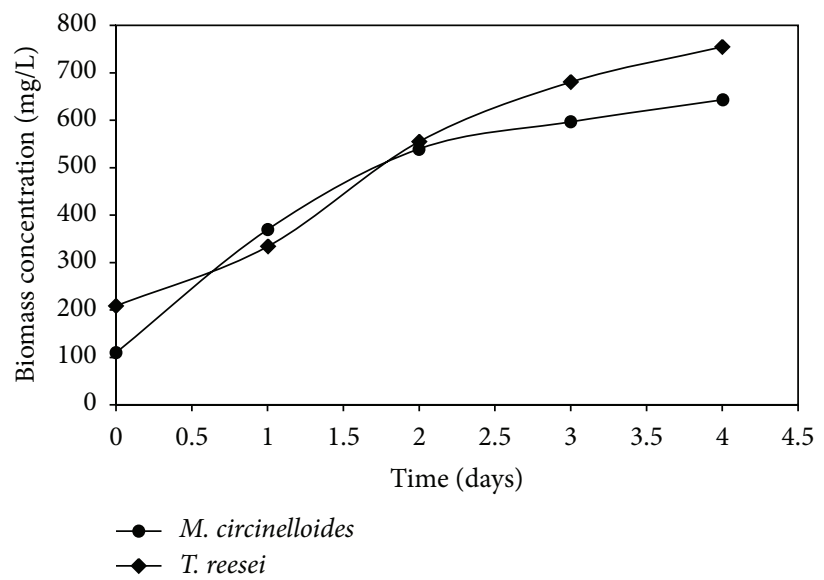

(a)

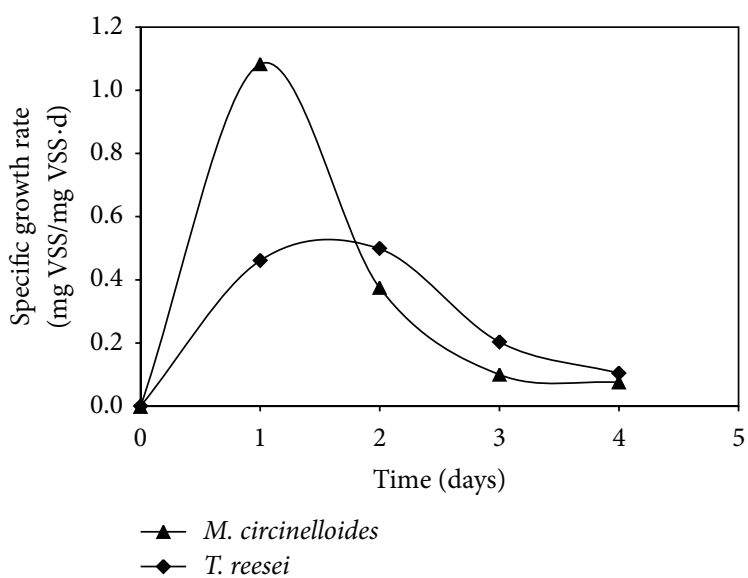

(b)

Figure 2: Fungal biomass production and specific growth rates profile during wastewater treatement. (a) Effect of different fungal strain inoculum (M. circinelloides and T. reesei) on biomass generation profile and (b) effect of different fungal strain inoculum on specific growth rates.

TABLE 3: Cost benefit analysis of fungal route for wastewater treatment.

\begin{tabular}{lcccc}
\hline $\begin{array}{l}\text { Plant capacity } \\
\text { MLD }\end{array}$ & Mucor circinelloides & Trichoderma reesei & Biodiesel production & $\begin{array}{c}\text { Profits in \$ } \\
\text { Gal }\end{array}$ \\
\hline 0.1 & Kg/day & Kg/day & 7.23 & 12.57 \\
1 & 14.2215 & 7.41 & 42.32 & 125.69 \\
10 & 142.215 & 74.1 & 423.19 & 1256.88 \\
200 & 1422.15 & 741 & 8463.87 & 25137.7 \\
\hline
\end{tabular}

$100 \mathrm{~m}^{3} /$ day and $200 \mathrm{MLD}$ plant, respectively (calculation is based on reported B100 price of 2.97 \$/gal [37]).

It shows the great opportunity for future sustainable wastewater treatment and bioenergy production at higher scale with high capacity plants. The further study needs to be done in the area of heterotrophic oleaginous fungal species and their fatty acids, such as triacylglycerols and sterol biosynthesis profiles with biochemical and genetic approaches for better understanding of their roles and regulations for future waste to energy applications.

\section{Conclusion}

Most aerobic wastewater treatment systems are energy intensive; the sludge produced from these systems creates the disposal problems, which need extra attention and expenses. The proposed fungal wastewater treatment technology offers very good waste to energy route by using low strength wastewater as potential substrate. The studied comparison of $M$. circinelloides and $T$. reesei for efficient wastewater treatment and bio-oil production found that the $M$. circinelloides was 


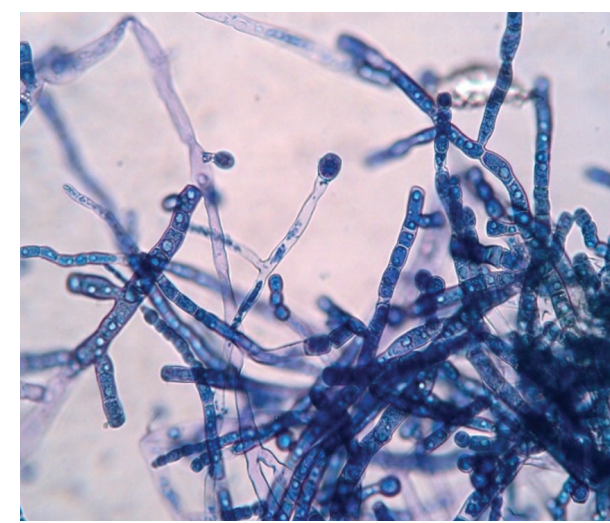

(a)

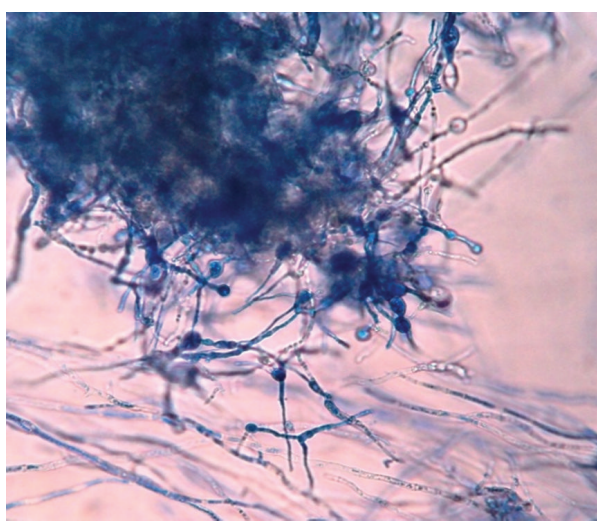

(c)

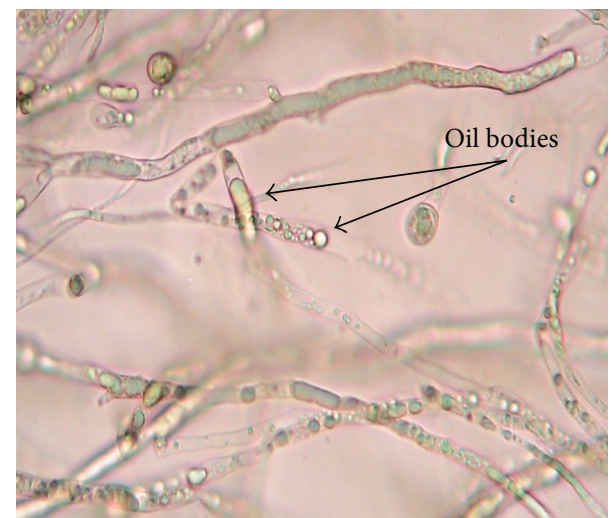

(b)

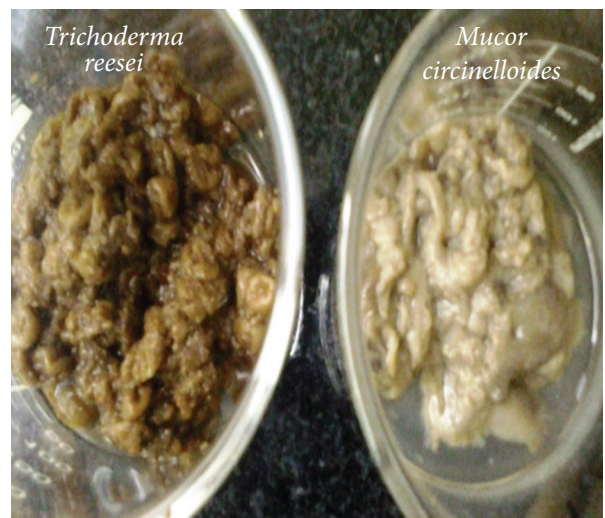

(d)

Figure 3: Microscopic observation of (a) M. circinelloides filamentous structure (Cotton Blue staining), (b) oil/lipid bodies stored in mycelia of M. circinelloides, (c) T. reesei filamentous structure (Cotton Blue staining), (d) fungal biomass collected at the end of the wastewater treatment (Left: T. reesei and right: M. circinelloides).

the best fungus with $88.72 \%$ of COD degradation ability with higher rate of degradation of $8.17 \mathrm{mg} \mathrm{COD} / \mathrm{mg} \mathrm{VSS} \cdot \mathrm{d}$ and bio-oil content $22.11 \% \mathrm{w} / \mathrm{w}$. Further optimization strategies of using modified or different fungal strains may increase the efficiency of the proposed route. The wastewater treatment with energy generation technology could be a sustainable model for future to achieve high treatment efficiency and bioresource.

\section{Conflict of Interests}

The authors declare that they have no conflict of interests regarding the publication of this paper.

\section{References}

[1] G. P. Minde, S. S. Magdum, and V. Kalyanraman, "Biogas as a sustainable alternative for current energy need of India," Journal of Sustainable Energy \& Environment, vol. 4, no. 3, pp. 121-132, 2013.

[2] I. Schulze, S. Hansen, S. Großhans et al., "Characterization of newly isolated oleaginous yeasts-Cryptococcus podzolicus, Trichosporon porosum and Pichia segobiensis," AMB Express, vol. 4, article 24, 2014.
[3] C. Hecht and C. Griehl, "Investigation of the accumulation of aromatic compounds during biogas production from kitchen waste," Bioresource Technology, vol. 100, no. 2, pp. 654-658, 2009.

[4] S. S. Magdum, S. More, and A. Nadaf, "Biochemical conversion of acid-pretreated water hyacinth (Eichhornia Crassipes) to alcohol using Pichia Stipitis NCIM3497,' International Journal of Advanced Biotechnology and Research, vol. 3, no. 2, pp. 585590, 2012.

[5] E. Theofanous, N. Kythreotou, G. Panayiotou, G. Florides, and I. Vyrides, "Energy production from piggery waste using anaerobic digestion: current status and potential in Cyprus," Renewable Energy, vol. 71, pp. 263-270, 2014.

[6] K. Rabaey and W. Verstraete, "Microbial fuel cells: novel biotechnology for energy generation," Trends in Biotechnology, vol. 23, no. 6, pp. 291-298, 2005.

[7] T. Schneider, S. Graeff-Hönninger, W. T. French et al., "Lipid and carotenoid production by oleaginous red yeast Rhodotorula glutinis cultivated on brewery effluents," Energy, vol. 61, pp. 3443, 2013.

[8] W.-F. Peng, C. Huang, X.-F. Chen et al., "Microbial conversion of wastewater from butanol fermentation to microbial oil by oleaginous yeast Trichosporon dermatis," Renewable Energy, vol. 55, pp. 31-34, 2013. 
[9] W. Zhou, W. Wang, Y. Li, and Y. Zhang, "Lipid production by Rhodosporidium toruloides Y2 in bioethanol wastewater and evaluation of biomass energetic yield," Bioresource Technology, vol. 127, pp. 435-440, 2013.

[10] S. S. Magdum, G. P. Minde, U. S. Adhyapak, and V. Kalyanraman, "An efficient biotreatment process for polyvinyl alcohol containing textile wastewater," Water Practice and Technology, vol. 8, no. 3-4, pp. 469-478, 2013.

[11] G. Abu-Elreesh and D. Abd-El-Haleem, "An effective lipidproducing fungal sp. strain DGB1 and its use for biodiesel production," African Journal of Biotechnology, vol. 12, no. 34, pp. 5347-5353, 2013.

[12] F. Chong, "1, 2 ZHANG Sha-Shal, WANG Feng-Qinl, XIE Huil, SONG An-Dong1 (1. College of Life Science, Henan Agricultural University, Zhengzhou 450002, China; 2. Experimental Management Centre, Zhongzhou University, Zhengzhou 450044, China); studies on culture conditi," Journal of Henan Agricultural University, vol. 6, Article ID 450002, 2009.

[13] J. M. Ageitos, J. A. Vallejo, P. Veiga-Crespo, and T. G. Villa, "Oily yeasts as oleaginous cell factories," Applied Microbiology and Biotechnology, vol. 90, no. 4, pp. 1219-1227, 2011.

[14] M. Koutb and F. M. Morsy, "A potent lipid producing isolate of Epicoccum purpurascens AUMC5615 and its promising use for biodiesel production," Biomass and Bioenergy, vol. 35, no. 7, pp. 3182-3187, 2011.

[15] L. Hui, C. Wan, D. Hai-Tao, C. Xue-Jiao, Z. Qi-Fa, and Z. YuHua, "Direct microbial conversion of wheat straw into lipid by a cellulolytic fungus of Aspergillus oryzae A-4 in solid-state fermentation," Bioresource Technology, vol. 101, no. 19, pp. 75567562, 2010.

[16] C. Huang, X. F. Chen, L. Xiong, X. D. Chen, and L. L. Ma, "Oil production by the yeast Trichosporon dermatis cultured in enzymatic hydrolysates of corncobs," Bioresource Technology, vol. 110, pp. 711-714, 2012.

[17] A. Chatzifragkou, A. Makri, A. Belka et al., "Biotechnological conversions of biodiesel derived waste glycerol by yeast and fungal species," Energy, vol. 36, no. 2, pp. 1097-1108, 2011.

[18] X. Meng, J. Yang, X. Xu, L. Zhang, Q. Nie, and M. Xian, "Biodiesel production from oleaginous microorganisms," Renewable Energy, vol. 34, no. 1, pp. 1-5, 2009.

[19] C. Ratledge, "Fatty acid biosynthesis in microorganisms being used for Single Cell Oil production,” Biochimie, vol. 86, no. 11, pp. 807-815, 2004.

[20] C. Xia, J. Zhang, W. Zhang, and B. Hu, "A new cultivation method for microbial oil production: cell pelletization and lipid accumulation by Mucor circinelloides," Biotechnology for Biofuels, vol. 4, no. 1, article 15, 2011.

[21] X. Peng and H. Chen, "Single cell oil production in solid-state fermentation by Microsphaeropsis sp. from steam-exploded wheat straw mixed with wheat bran," Bioresource Technology, vol. 99, no. 9, pp. 3885-3889, 2008.

[22] M. N. Siddiquee and S. Rohani, "Lipid extraction and biodiesel production from municipal sewage sludges: a review, Renewable and Sustainable Energy Reviews, vol. 15, no. 2, pp. 10671072, 2011.

[23] M. J. Sheedlo, "A review of the processes of biodiesel production," MMG 445 Basic Biotechnology EJournal, vol. 4, no. 1, pp. 61-65, 2008.

[24] APHA, "Standard methods for the examination of water and wastewater," American Water Works Association/American Public Works Association/Water Environment Federation, 2012.
[25] S. S. Magdum, G. P. Minde, and V. Kalyanraman, "Rapid determination of indirect cod and polyvinyl alcohol from textile desizing wastewater," Pollution Research, vol. 32, no. 3, pp. 515519, 2013.

[26] S. Fakas, S. Papanikolaou, A. Batsos, M. Galiotou-Panayotou, A. Mallouchos, and G. Aggelis, "Evaluating renewable carbon sources as substrates for single cell oil production by Cunninghamella echinulata and Mortierella isabellina," Biomass and Bioenergy, vol. 33, no. 4, pp. 573-580, 2009.

[27] S. Papanikolaou, M. Galiotou-Panayotou, S. Fakas, M. Komaitis, and G. Aggelis, "Lipid production by oleaginous Mucorales cultivated on renewable carbon sources," European Journal of Lipid Science and Technology, vol. 109, no. 11, pp. 1060-1070, 2007.

[28] S. Papanikolaou, P. Diamantopoulou, A. Chatzifragkou, A. Philippoussis, and G. Aggelis, "Suitability of low-cost sugars as substrates for lipid production by the fungus Thamnidium elegans," Energy and Fuels, vol. 24, no. 7, pp. 4078-4086, 2010.

[29] C. N. Economou, G. Aggelis, S. Pavlou, and D. V. Vayenas, "Modeling of single-cell oil production under nitrogen-limited and substrate inhibition conditions," Biotechnology and Bioengineering, vol. 108, no. 5, pp. 1049-1055, 2011.

[30] C. N. Economou, G. Aggelis, S. Pavlou, and D. V. Vayenas, "Single cell oil production from rice hulls hydrolysate," Bioresource Technology, vol. 102, no. 20, pp. 9737-9742, 2011.

[31] A. Chatzifragkou, S. Fakas, M. Galiotou-Panayotou, M. Komaitis, G. Aggelis, and S. Papanikolaou, "Commercial sugars as substrates for lipid accumulation in Cunninghamella echinulata and Mortierella isabellina fungi," European Journal of Lipid Science and Technology, vol. 112, no. 9, pp. 1048-1057, 2010.

[32] J. P. Wynn, A. Kendrick, and C. Ratledge, "Sesamol as an inhibitor of growth and lipid metabolism in Mucor circinelloides via its action on malic enzyme," Lipids, vol. 32, no. 6, pp. 605-610, 1997.

[33] D. Mitra, M. L. Rasmussen, P. Chand et al., "Value-added oil and animal feed production from corn-ethanol stillage using the oleaginous fungus Mucor circinelloides," Bioresource Technology, vol. 107, pp. 368-375, 2012.

[34] S. Bellou, A. Makri, D. Sarris et al., "The olive mill wastewater as substrate for single cell oil production by Zygomycetes," Journal of Biotechnology, vol. 170, no. 1, pp. 50-59, 2014.

[35] S. Sankaran, S. K. Khanal, N. Jasti, B. Jin, A. L. Pometto, and J. H. Van Leeuwen, "Use of filamentous fungi for wastewater treatment and production of high value fungal byproducts: a review," Critical Reviews in Environmental Science and Technology, vol. 40, no. 5, pp. 400-449, 2010.

[36] G. Vicente, L. F. Bautista, F. J. Gutiérrez et al., "Direct transformation of fungal biomass from submerged cultures into biodiesel," Energy \& Fuels, vol. 24, no. 5, pp. 3173-3178, 2010.

[37] J. E. Conway, Buckrammer's Tales: The Continuing Catboat Summers Adventures, AuthorHouse, 2014. 

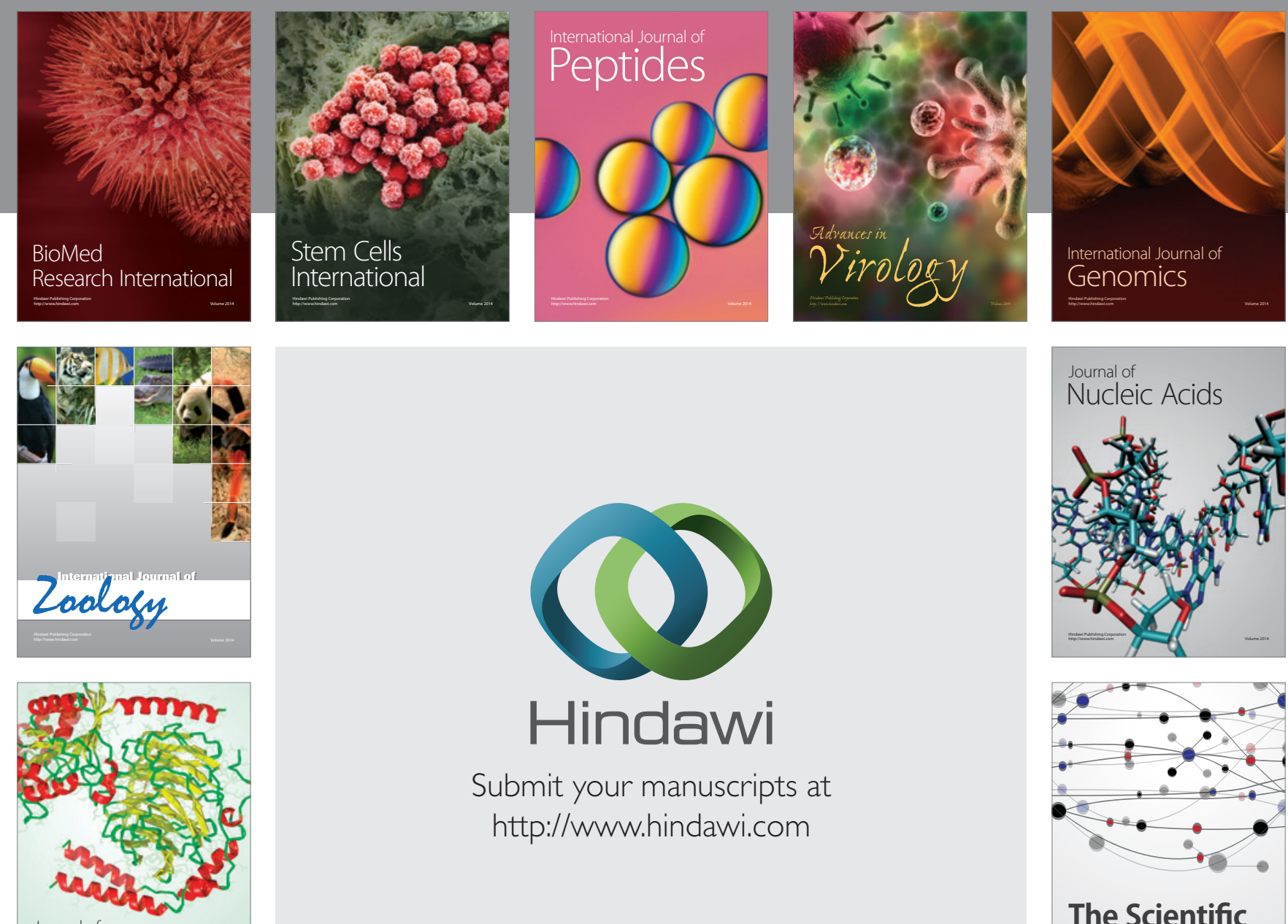

Submit your manuscripts at

http://www.hindawi.com

Journal of
Signal Transduction
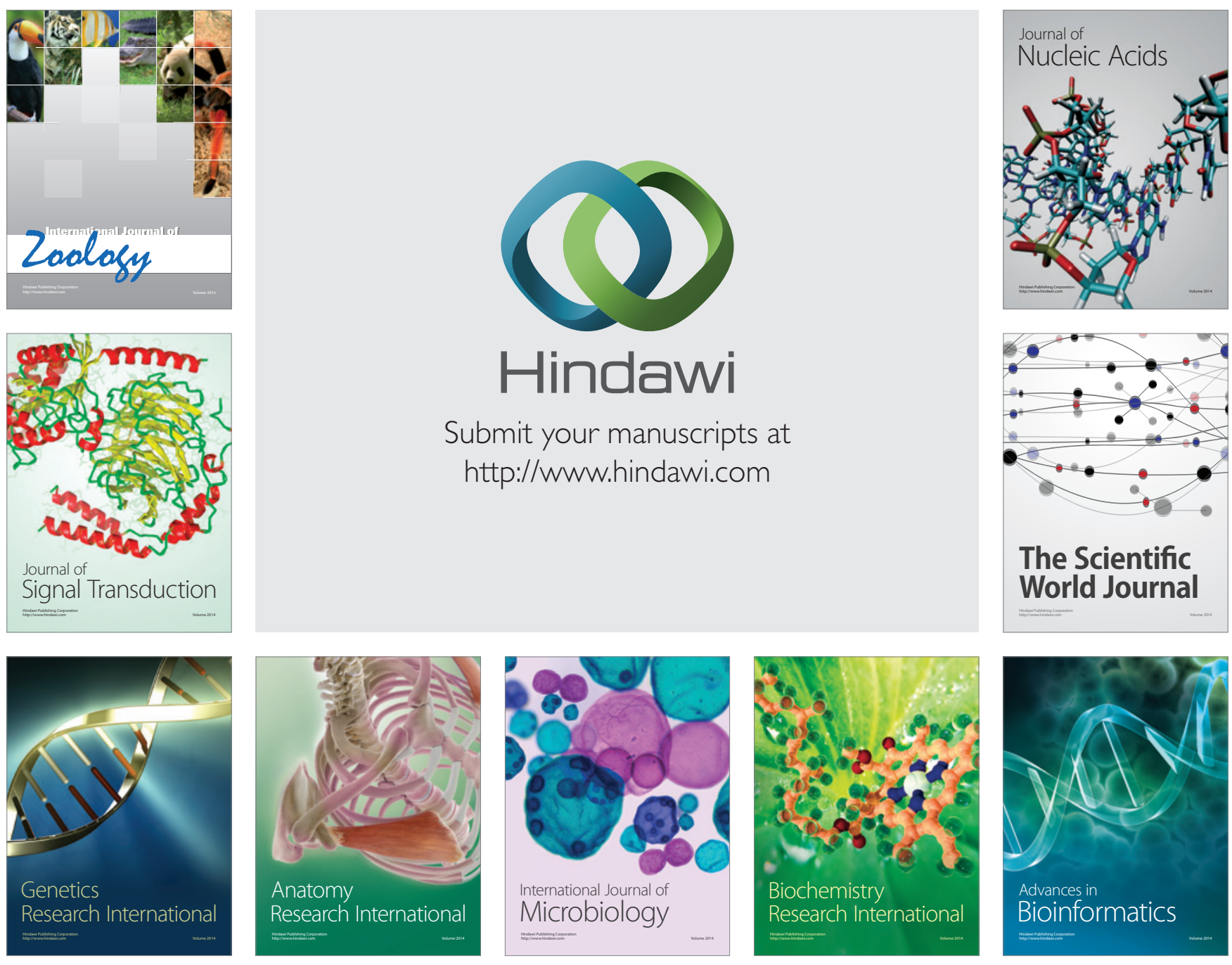

The Scientific World Journal
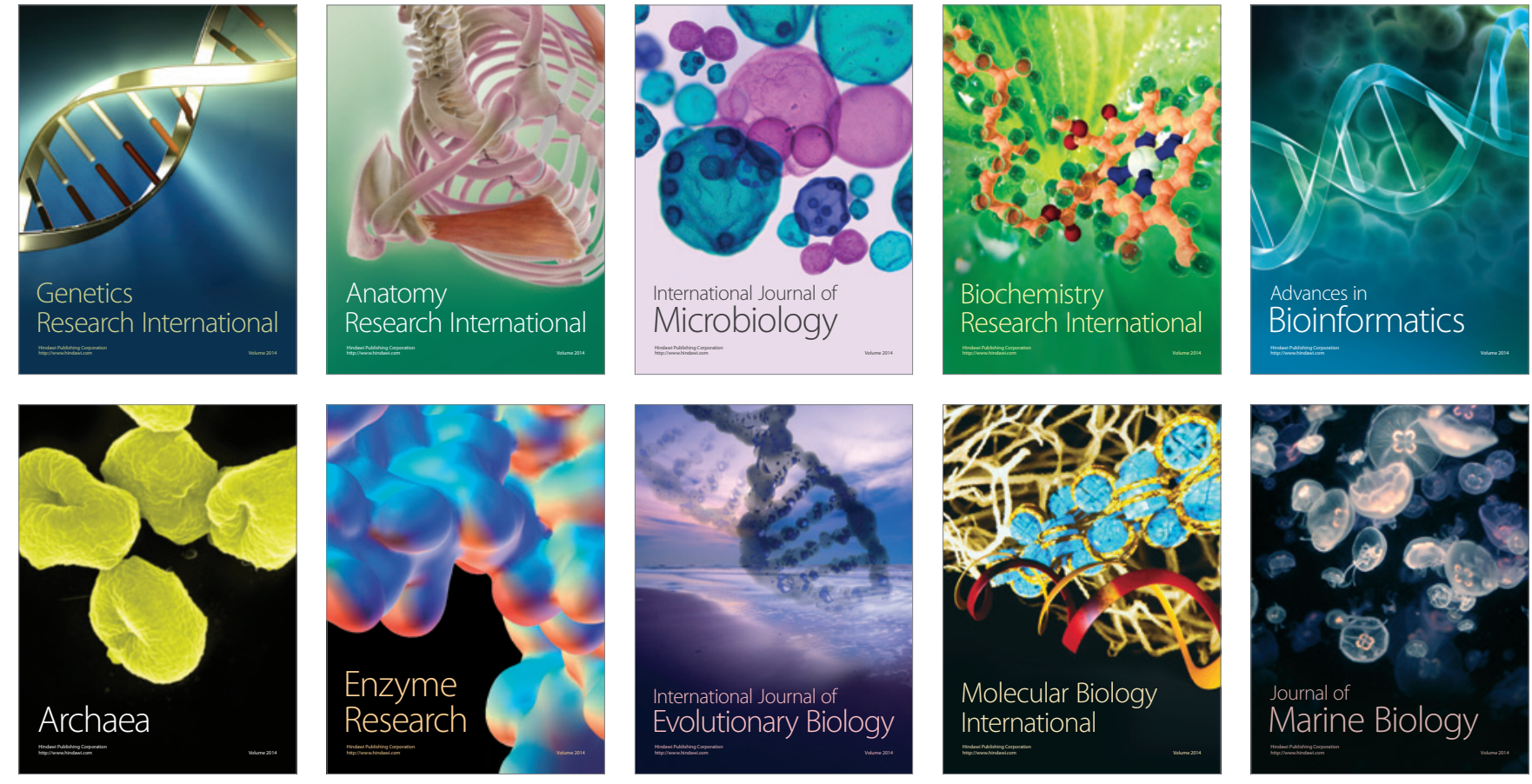